\title{
Erratum: Emerging topics in FXTAS
}

\author{
Deborah A Hall ${ }^{1 *}$, Rachael C Birch², Mathieu Anheim ${ }^{3,4,5}$, Aia E Jønch ${ }^{6}$, Elizabeth Pintado ${ }^{7}$, Joan A O'Keefe ${ }^{8}$, \\ Julian N Trollor ${ }^{2,13}$, Glenn T Stebbins ${ }^{1}$, Randi J Hagerman ${ }^{9}$, Stanley Fahn ${ }^{10}$, Elizabeth Berry-Kravis ${ }^{1,11}$ \\ and Maureen A Leehey ${ }^{12}$
}

\section{Erratum}

Following the publication of our article [1], we noticed that Dr Joan A O'Keefe and Dr Stanley Fahn had inadvertently been omitted from the authors' contributions section. In addition, Dr Joan A O'Keefe was incorrectly listed in the author list as Joanne O'Keefe. The author list has now been corrected and the amended authors' contributions section is included below.

\section{Authors' contributions}

$\mathrm{DH}$ : manuscript planning, drafting of initial manuscript, final manuscript editing and submission. EBK: drafting of initial manuscript, final manuscript editing. $\mathrm{RH}$ : drafting of initial and final manuscript editing. RB: drafting of initial manuscript, final manuscript editing. JAO: drafting of initial manuscript, final manuscript editing. JNT: drafting of initial manuscript, final manuscript editing. ML: manuscript planning, drafting of initial manuscript, final manuscript editing. MA: drafting of the manuscript, critical revision of the manuscript. AEJ: drafting of initial manuscript, final manuscript editing. EP drafting of initial manuscript, final manuscript editing. SF: final manuscript editing. GTS: final manuscript editing. All authors read and approved the final manuscript.

\section{Author details}

${ }^{1}$ Department of Neurological Sciences, Rush University, Chicago, IL, USA. ${ }^{2}$ Department of Developmental Disability Neuropsychiatry, School of Psychiatry, University of New South Wales, Sydney, Australia. ${ }^{3}$ Département de Neurologie, Hôpitaux Universitaires de Strasbourg, Hôpital de Hautepierre, Strasbourg, Cedex 67098, France. ${ }^{4}$ Institut de Génétique et de Biologie Moléculaire et Cellulaire (IGBMC), INSERM-U964/CNRS-UMR7104/Université de Strasbourg, Illkirch 67404, France. ${ }^{5}$ Fédération de Médecine Translationnelle de Strasbourg (FMTS), Université de Strasbourg, Strasbourg, France.

${ }^{6}$ Department of clinical Genetics, Kennedy Center, Rigshospitalet, Copenhagen University Hospital, Copenhagen, Denmark. 'Department of Medical Biochemistry and Molecular Biology, University of Seville, Sevilla, Spain. ${ }^{8}$ Department of Anatomy \& Cell Biology, Rush University, Chicago, IL, USA. ${ }^{9}$ Department of Pediatrics \& M.I.N.D. Institute, University of California at Davis Medical Center, Sacramento, CA, USA. ${ }^{10}$ Department of Neurology, Columbia University, New York, NY, USA. ${ }^{11}$ Departments of Pediatrics and Biochemistry, Rush University, Chicago, IL, USA. ${ }^{12}$ Department of Neurology, University of Colorado at Denver, Denver, CO, USA. ${ }^{13}$ Centre for Healthy Brain Ageing, University of New South Wales, Sydney, Australia.
Received: 9 March 2015 Accepted: 10 March 2015 Published online: 08 April 2015

\section{References}

1. Hall DA, Birch RC, Anheim M, Jønch AE, Pintado E, O'Keefe J, et al. Emerging topics in FXTAS. J Neurodev Disord. 2014;6:31.

\footnotetext{
* Correspondence: Deborah_A_Hall@rush.edu

'Department of Neurological Sciences, Rush University, Chicago, IL, USA
}

Full list of author information is available at the end of the article

\section{Submit your next manuscript to BioMed Central and take full advantage of:}

- Convenient online submission

- Thorough peer review

- No space constraints or color figure charges

- Immediate publication on acceptance

- Inclusion in PubMed, CAS, Scopus and Google Scholar

- Research which is freely available for redistribution 